\title{
SEDIMENTS QUALITY AND POTENTIAL USES OF DREDGED MATERIAL: A CASE STUDY (PORTUGAL)
}

\author{
Assane Luis Pena ${ }^{1 *}$, Maria Virginia Alves Martins ${ }^{2,3}$, Paulo Miranda $^{3}$, Denise Lara Terroso ${ }^{3}$, Fernando Rocha ${ }^{3}$
}

1 Universidade Pedagógica - Moçambique, Departamento de Ciências da Terra e Ambiente. Rua D. Francisco de Almeida $2^{\circ}$ Bairro, Ponta-Gêa, 737/ 751 - Beira - Moçambique - Caixa-postal: 2025. assanepena@gmail.com

2 Universidade do Estado do Rio de Janeiro, Faculdade de Geologia, Departamento de Estratigrafia e Paleontologia. Av. São Francisco Xavier, 524, sala 2020A, Maracanã. 20550-013 Rio de Janeiro, RJ, Brazil. virginia.martins@ua.pt

3 Universidade de Aveiro, GeoBioTec, Departamento de Geociências, Campus de Santiago, 3810-193 Aveiro, Portugal. pfnmiranda@gmail.com, laraterroso@ua.pt, tavares.rocha@ua.pt

*Corresponding author, assanepena@gmail.com

SCREENED BY

$\checkmark$ iThenticate

Citation:

Pena, A., Martins, M.V.A., E., Miranda, P., Terroso, D.L., Rocha, F., 2017. Sediments quality and potential uses of dredged material: a case study (Portugal). Journal of Sedimentary Environments, 2 (2): 81-98

\section{Abstract}

This work intends to access the sediments quality and to suggest potential uses of dredged material off the mouth of Figueira da Foz Harbor (FFH; Portugal), at a frequently dredge area in order to keep port accessibility. Thirty-six sediment samples collected at an area of about $4 \mathrm{~km}^{2}$ were submitted to textural, mineralogical (X-Ray Diffraction techniques) and geochemical (ICP-MS) analyses.

Results evidenced that bottom sediments in the study area are composed mainly of sand. Fine fraction increases with distance to the FFH mouth. The mineralogical and geochemical analyses performed in 14 samples (with enough fine fraction for both analyses) indicate that the sediments sources are mostly related to the littoral drift and Mondego River, which flows into the region.

Preliminary results of this work indicate that in general the sediments are clean, which allows the disposal of the dredged materials without restrictions, for instance, in the aquatic environment or beach nourishment. However, an enrichment of $\mathrm{Cd}$ was observed in few stations, probably

related to anthropogenic sources of pollution. Cadmium in high concentrations can provoke environmental problems. It has biomagnification effect and is a potential carcinogen for humans. According to Portuguese regulation sediments collected, in the stations FF1, FF13, FF24 and FF33, contaminated dredged materials (Class 4) can be dumped on land, in a waterproofed place; and, in the station FF18, corresponding to highly contaminated dredged materials (Class 5) should be sent for prior treatment and/or dump of duly authorized waste, being forbidden their immersion. However, more detailed analyses and subsequent on-site monitoring studies should be required to achieve conclusive results and to analyse the persistence of pollutants in this region.

Keywords: Harbor dredging. Sediments. Quality of dredged material. Application of dredged material. Contamination. Coastal area. 


\section{Introduction}

The bottom sediments of the river estuaries have a wide range of scientific and economic interests (Iannace, 2009). They are a mixture of fluvial and marine materials. Their texture and composition are related to their origin and geodynamic processes to which they have been submmited both at sea and on continental areas. Bottom sediments at river estuaries experience the influence of several natural and man-made factors (Cortesão and Vale, 1995).

Removal of sediments from a river, estuary and other kind of water bodies, either from bed or margins, is being carried out for the purpose of marketing these kind of materials, for example, for the construction industry (Paiva, 2011; Silva, 2011). However, dredging activities have in general as first objective to allow the navigability of a river stretch, estuary and to enable port activities (Verfaillie et al., 2005; Coelho et al., 2011).

Dredging activities are necessary and unavoidable in port and estuarine areas in order to keep operational canals, rivers and harbors (Kondolf et al., 2014). Otherwise, dredged sediments have been identified as alternative resources to reduce the demand for traditionally exploited natural resources (Tamuno et al., 2009). Increasing difficulties to obtain these resources and the restrictions growing to explore new quarries are some examples of factors conditioning the exploitation of surface aggregates, thus favoring the use of coastal and marine bottom sediments (Kondolf, et al., 2014). Nevertheless, the availability of sediments has been declining along the coastline of many countries (Tamuno et al., 2009).

The management of dredged materials is a worldwide problem and the traditional solution of dumping them at sea has been progressively conditioned by national and international regulations. Nevertheless, this practice has not been reduced. For example, in Portugal, about 2.6 million tons of dredging materials were dumped at sea only in 2005, which resulted in economic losses (Velosa and Cachim, 2011).

Despite the fact that dredged sediments are considered a promising product, they are frequently used without prior scientific studies, in a number of applications, including erosion control, aquaculture, agriculture, beach feeding, and stabilization of the coastline as raw material for the production of aggregates or other products of construction (Paixão, 2004). On the other hand, during sediment dredging it is possible that hazardous chemicals associated with the sediments are released into the aquatic environment, causing harmful environmental impacts to the aquatic systems. In addition, it is estimated that in Portugal, from total dredged materials, about $5 \%$ are poorly contaminated and $1 \%$ are contaminated (Paixão, 2004).

This practice entails serious and progressive environmental problems and, therefore, calls for the need of environmentally sustainable and economically viable solutions. In Portugal, the Ministerial Order n. ${ }^{\circ}$ 209/2004 (Portaria n. ${ }^{\circ}$ 209/2004) classifies the dredged materials. When the sediments are not completely contaminated, the Ministerial Order n. ${ }^{\circ}$ 1450/2007 (Portaria n. ${ }^{\circ}$ 1450/2007) recommends the development of environmentally sustainable measures or solutions that include, textural, mineralogical and geochemical studies (determination of the amount of potentially toxic organic compounds and metals), among other analyses, before the use of dredged materials.

The sedimentary cartography of the Portuguese continental shelf has been carried out in view of applications associated with a wide range of activities, such as fishing and leisure activities, identification of areas favorable to the exploration of inert materials, delimitation of anchorages, installation of submarine structures to exploit wave energy, military activities and studies of sound propagation in marine environment (Luíz et al., 2006).

According to Martins et al. (2012), there are significant and well-marked differences in the sediments present in several sectors of the Portuguese Continental Shelf. The area of Figueira da Foz Harbor (FFH; Portugal), where this study was performed, offered and still offers conditions for this kind of studies, as it was a natural mouth that has being experienced important artificial modifications over time (Cunha et al., 2006).

According to Cunha et al. (1995), the human interventions greatly influenced the natural dynamics of Mondego River estuary. These authors noticed that the removal of sediments is done by dredging or extraction on the beach and in the distal sector of the estuary and is conditioned by the natural influxes. This activity creates the overexploitation of sediments, resulting in harmful consequences, such as: sharp sandy deficit of the coast, reducing the efficacy of the fluvial self-drainage; silting tendency of the submarine bar of Mondego River; and deposition of marine sediments in the port area. However, Cunha et al. (1995) observed that the natural response to the artificial removals is rapid. Silva et al. (2015), studying the sedimentary dynamics of this region, observed that excavations caused by dredging operations carried out at the FFH mouth are later filled with sediments from the coastal drift and tidal current activity and excavations preservation depends on the frequency of extreme wave's events. 


\subsection{The main goals}

The main objective of this work is to evaluate the bottom sediments quality from the FFH mouth (Fig. 1), an area which is submitted to frequent dredging, and to suggest potential applications for dredge materials.

\section{Study area}

The study area is located at the FFH mouth (Portugal), associated with the Mondego River estuary (Fig. 1). The Mondego River is born in the Serra da Estrela, at $1547 \mathrm{~m}$ altitude, at the "Mondeguinho" font. It runs for about 300 $\mathrm{km}$ until reaches the Atlantic Ocean, in Figueira da Foz city (Cunha et al., 2006).

The basin of the Mondego River has a total area of 6644 $\mathrm{km}^{2}$ (Rocha and Freitas, 1998). Along its route, this river crosses several rocky formations of the Serra da Estrela, granite and metamorphic formations on the southwestern Beira plateau, shale and quartzite formations between Penacova and Coimbra (called Alto Mondego). The terminal section (called Baixo Mondego), about $40 \mathrm{~km}$ long, runs through an alluvial plain, extremely fertile and where are located some of the most productive rice fields in Europe. Baixo Mondego region has been marked by the degradation of water quality.

The maritime access to port facilities is carried out through a mouth that is delimited by two breakwaters (north and south) and by the navigation channel (Silva et al., 2015). The coast has NNW-SSE direction at north of Mondego River estuary and up to Cape Mondego, and S-SSW orientation at south (Cunha et al., 1995; Silva et al., 2015).

According to the Portuguese Institute of Sea and Atmosphere (Instituto Português do Mar e da Atmosfera IPMA), climate in this region is temperate with dry and mild summers. Annual average precipitation is about $1200 \mathrm{~mm}$. Precipitation is higher in the mountainous areas, with an annual average of about $2800 \mathrm{~mm}$, and drops to $900 \mathrm{~mm}$ in coastal zones. About $73 \%$ of precipitation is concentrated between October and March (Rocha and Freitas, 1998).

According to Cunha et al. (1995), the region of FFH mouth is characterized by strong winds, being the most frequent directions from N and NW quadrants. The wind regime is very irregular throughout the year, but one of the most constant characteristics is the predominance of north winds (northeastern) in the summer months. Strong SW winds reaching frequently velocities greater than $20 \mathrm{~km} / \mathrm{h}$ are more frequent in the winter season. Strong winds from SW quadrant can generate waves, which can propagate with intensity inside the Mondego River estuary.
Tides at the mouth of Mondego River estuary are semidiurnal and mesotidal (Bacelar-Nicolau et al., 2003). Distribution of significant wave height and wave period reaches highest frequency from NW and for the classes 0.5$2.5 \mathrm{~m}(75 \%)$ and 5-9 s (77\%), respectively (Silva et al., 2015). Close to FFH mouth and Cape Mondego, the incident waves are refracted, dispersed, change the propagation direction to $\mathrm{W}$ and decrease in height (Freire et al., 2004).

The longitudinal transport of sediments along this coastal sector is preferably from north to south. The engineering structures of FFH induced large accumulation of sediments at north of the jetties, at Figueira da Foz beach. This feature evidences that sediments provided by coastal drift towards the south are being accumulated at north of the FFH jetties. This process was analyzed in several researches (Abecasis et al., 1962; Cunha et al., 1995; Silva et al., 2012, 2015). On the contrary, the area at southern of the Mondego River estuary is currently in erosion risk due to anthropogenic actions (Cunha et al., 2006).

\section{Material and methods}

This work is based on the study of 36 surface sediment samples collected at about 9-12 $\mathrm{m}$ depth, off the FFH mouth (Table 1) with a Petit Ponar grab during a scientific campaign held in September 2015. The work was carried out as part of a research project aiming to study the sedimentary dynamics at the FFH mouth, conducted by the Universidade de Aveiro, in collaboration with Port Authority of Aveiro, SA. The study area is located between the parallel of $40^{\circ} 10^{\prime} \mathrm{N}$ and the meridian of $8^{\circ} 52^{\prime} \mathrm{W}$ (Cape Mondego) and extends to about $2.5 \mathrm{~km}$ south of Mondego River mouth (Fig. 1). The sedimentary samples were submitted to textural, mineralogical and geochemical analyses.

\subsection{Textural analysis}

Sediment samples were dried in an oven at $50^{\circ} \mathrm{C}$ for about 48 to 72 hours. Samples were manually quartered in order to obtain a representative subsample (about 150-250 gr of sediment) and weighed. The initial dry weight of each subsample was recorded. The sand samples granulometry was determined by dry screening. In sandy mud samples, fines $(<63 \mu \mathrm{m})$ were separated by wet sieving. Sediment fractions $>63 \mu \mathrm{m}$ were separated using a series of sieves (4 $\mathrm{mm}, 2 \mathrm{~mm}, 1 \mathrm{~mm}, 500 \mu \mathrm{m}, 250 \mu \mathrm{m}, 125 \mu \mathrm{m}$ and $63 \mu \mathrm{m})$ and a mechanical sieve shaker. The percentage of each sediment fraction was determined. A number of textural parameters (sediment mean grain size, calibration/selection, asymmetry and kurtosis) were estimated, using the Gradistat v.8 software, according to Folk and Ward (1957). 

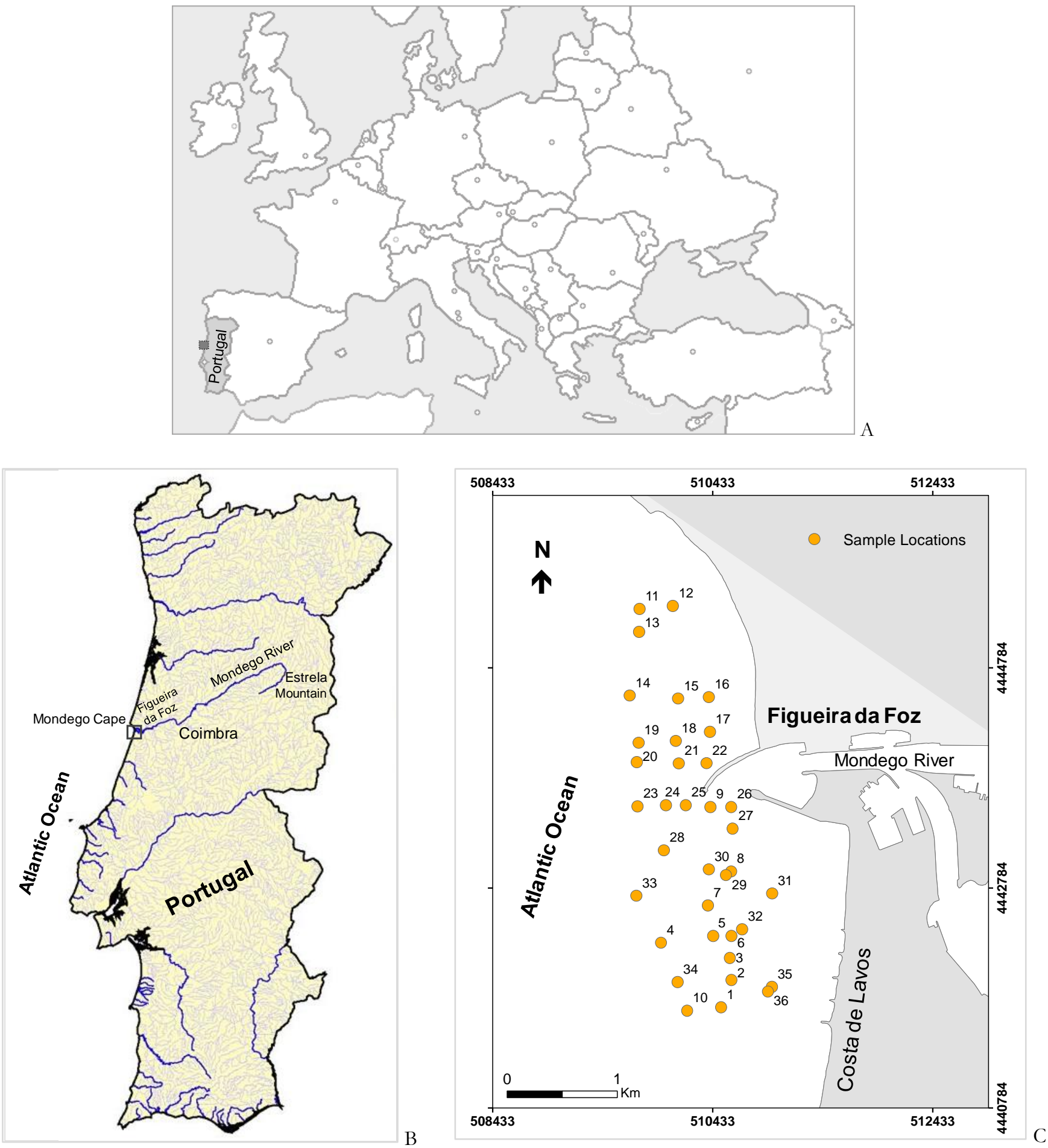

Fig. 1. The location of the study area in Portugal (Center West). B. Mondego River between the main Portuguese rivers (the study area situated at Figueira da Foz Region is marked). C. Studied stations off the Figueira da Foz Harbour (stations are marked with balls and numbers). 
Tab. 1. Studied stations location, collected at about 9-12 m depth, and textural data. Legend: St. Ref. - Station Reference. SMGS Sediment Mean Grain Size. Sediment description based on SMGS.

\begin{tabular}{|c|c|c|c|c|c|c|c|}
\hline \multirow{2}{*}{$\begin{array}{l}\text { St. } \\
\text { Ref. }\end{array}$} & \multicolumn{2}{|c|}{ Metric Coordinates } & \multicolumn{5}{|c|}{ According to Folk \& Ward (1957) } \\
\hline & $\mathbf{X}$ & $\mathbf{Y}$ & $\begin{array}{l}\text { SMGS } \\
(\mu \mathrm{m})\end{array}$ & $\begin{array}{c}\text { Sediment } \\
\text { Description }\end{array}$ & Sorting & Skewness & Kurtosis \\
\hline FF1 & 510508.4 & 4441700.1 & 67.4 & Very Fine Sand & Poorly Sorted & $\begin{array}{l}\text { Very Fine } \\
\text { Skewed }\end{array}$ & Platykurtic \\
\hline FF2 & 510602.7 & 4441946.9 & 230.2 & Fine Sand & $\begin{array}{l}\text { Moderately } \\
\text { Sorted }\end{array}$ & Coarse Skewed & Mesokurtic \\
\hline FF3 & 510588.3 & 4442147.1 & 240.2 & Fine Sand & $\begin{array}{l}\text { Moderately } \\
\text { Sorted }\end{array}$ & Coarse Skewed & Mesokurtic \\
\hline FF4 & 509963.3 & 4442285.2 & 271.9 & Medium Sand & $\begin{array}{l}\text { Moderately } \\
\text { Sorted }\end{array}$ & Symmetrical & Mesokurtic \\
\hline FF5 & 510436.5 & 4442347.5 & 80.85 & Very Fine Sand & $\begin{array}{l}\text { Very Poorly } \\
\text { Sorted }\end{array}$ & Fine Skewed & Mesokurtic \\
\hline FF6 & 510602.2 & 4442347.7 & 149.2 & Fine Sand & $\begin{array}{l}\text { Moderately } \\
\text { Sorted }\end{array}$ & Symmetrical & $\begin{array}{c}\text { Very } \\
\text { Leptokurtic }\end{array}$ \\
\hline FF7 & 510388.8 & 4442624.9 & 245.4 & Fine Sand & $\begin{array}{l}\text { Moderately } \\
\text { Sorted }\end{array}$ & Coarse Skewed & Platykurtic \\
\hline FF8 & 510601.3 & 4442933.5 & 358.4 & Medium Sand & $\begin{array}{l}\text { Moderately Well } \\
\text { Sorted }\end{array}$ & Symmetrical & Leptokurtic \\
\hline FF9 & 510411.2 & 4443519.0 & 540.3 & Coarse Sand & $\begin{array}{l}\text { Moderately } \\
\text { Sorted }\end{array}$ & Symmetrical & Mesokurtic \\
\hline FF10 & 510200.8 & 4441668.8 & 222.9 & Fine Sand & $\begin{array}{l}\text { Moderately } \\
\text { Sorted }\end{array}$ & $\begin{array}{l}\text { Very Coarse } \\
\text { Skewed }\end{array}$ & $\begin{array}{c}\text { Very } \\
\text { Leptokurtic }\end{array}$ \\
\hline FF11 & 509767.8 & 4445320.0 & 387.6 & Medium Sand & $\begin{array}{c}\text { Moderately Well } \\
\text { Sorted }\end{array}$ & Symmetrical & Leptokurtic \\
\hline FF12 & 510070.0 & 4445347.4 & 456.3 & Medium Sand & $\begin{array}{c}\text { Moderately Well } \\
\text { Sorted }\end{array}$ & Coarse Skewed & Platykurtic \\
\hline FF13 & 509762.2 & 4445112.3 & 354.8 & Medium Sand & $\begin{array}{l}\text { Moderately } \\
\text { Sorted }\end{array}$ & Symmetrical & Leptokurtic \\
\hline FF14 & 509678.3 & 4444533.5 & 196.4 & Fine Sand & Poorly Sorted & Fine Skewed & $\begin{array}{c}\text { Very } \\
\text { Leptokurtic }\end{array}$ \\
\hline FF15 & 510118.2 & 4444506.2 & 225.5 & Fine Sand & $\begin{array}{l}\text { Moderately Well } \\
\text { Sorted }\end{array}$ & Coarse Skewed & Platykurtic \\
\hline FF16 & 510397.3 & 4444517.8 & 284.9 & Medium Sand & $\begin{array}{l}\text { Moderately Well } \\
\text { Sorted }\end{array}$ & Fine Skewed & Platykurtic \\
\hline FF17 & 510406.4 & 4444202.6 & 525.0 & Coarse Sand & $\begin{array}{l}\text { Moderately } \\
\text { Sorted }\end{array}$ & Symmetrical & Mesokurtic \\
\hline FF18 & 510097.2 & 4444120.8 & 175.8 & Fine Sand & $\begin{array}{l}\text { Moderately Well } \\
\text { Sorted }\end{array}$ & Symmetrical & $\begin{array}{c}\text { Very } \\
\text { Leptokurtic }\end{array}$ \\
\hline FF19 & 509758.5 & 4444104.1 & 95.70 & Very Fine Sand & Poorly Sorted & $\begin{array}{l}\text { Very Fine } \\
\text { Skewed }\end{array}$ & Leptokurtic \\
\hline FF20 & 509743.0 & 4443928.5 & 104.6 & Very Fine Sand & Poorly Sorted & $\begin{array}{l}\text { Very Fine } \\
\text { Skewed }\end{array}$ & $\begin{array}{c}\text { Very } \\
\text { Leptokurtic }\end{array}$ \\
\hline FF21 & 510123.9 & 4443915.9 & 177.4 & Fine Sand & $\begin{array}{l}\text { Moderately Well } \\
\text { Sorted }\end{array}$ & Symmetrical & Leptokurtic \\
\hline FF22 & 510376.2 & 4443917.1 & 303.6 & Medium Sand & $\begin{array}{l}\text { Moderately Well } \\
\text { Sorted }\end{array}$ & Symmetrical & Leptokurtic \\
\hline FF23 & 509749.3 & 4443526.5 & 176.1 & Fine Sand & Poorly Sorted & Fine Skewed & $\begin{array}{c}\text { Very } \\
\text { Leptokurtic }\end{array}$ \\
\hline
\end{tabular}


Tab. 1. (cont.) Studied stations location, collected at about 9-12 m depth, and textural data. Legend: St. Ref. - Station Reference. SMGS - Sediment Mean Grain Size. Sediment description based on SMGS.

\begin{tabular}{|c|c|c|c|c|c|c|c|}
\hline \multirow{2}{*}{$\begin{array}{l}\text { St. } \\
\text { Ref. }\end{array}$} & \multicolumn{2}{|c|}{ Metric Coordinates } & \multicolumn{5}{|c|}{ According to Folk \& Ward (1957) } \\
\hline & $\mathbf{x}$ & $\mathbf{Y}$ & $\begin{array}{c}\text { SMGS } \\
(\mu \mathrm{m})\end{array}$ & $\begin{array}{c}\text { Sediment } \\
\text { Description }\end{array}$ & Sorting & Skewness & Kurtosis \\
\hline FF24 & 510006.2 & 4443536.3 & 203.2 & Fine Sand & $\begin{array}{l}\text { Moderately Well } \\
\text { Sorted }\end{array}$ & Coarse Skewed & Mesokurtic \\
\hline FF25 & 510188.0 & 4443536.5 & 313.3 & Medium Sand & $\begin{array}{l}\text { Moderately Well } \\
\text { Sorted }\end{array}$ & Fine Skewed & Leptokurtic \\
\hline FF26 & 510601.4 & 4443519.2 & 320.0 & Medium Sand & Moderately Sorted & Symmetrical & Leptokurtic \\
\hline FF27 & 510614.3 & 4443324.4 & 288.2 & Medium Sand & Moderately Sorted & Symmetrical & Mesokurtic \\
\hline FF28 & 509988.6 & 4443124.9 & 147.3 & Fine Sand & Poorly Sorted & Fine Skewed & Very Leptokurtic \\
\hline FF29 & 510553.4 & 4442900.3 & 582.3 & Coarse Sand & Moderately Sorted & Fine Skewed & Mesokurtic \\
\hline FF30 & 510395.6 & 4442952.4 & 565.9 & Coarse Sand & Moderately Sorted & Symmetrical & Mesokurtic \\
\hline FF31 & 510971.1 & 4442734.4 & 282.5 & Medium Sand & Moderately Sorted & Symmetrical & Mesokurtic \\
\hline FF32 & 510699.4 & 4442407.3 & 309.1 & Medium Sand & $\begin{array}{c}\text { Moderately Well } \\
\text { Sorted }\end{array}$ & Symmetrical & Leptokurtic \\
\hline FF33 & 509738.0 & 4442713.5 & 177.2 & Fine Sand & $\begin{array}{l}\text { Moderately Well } \\
\text { Sorted }\end{array}$ & Coarse Skewed & Very Leptokurtic \\
\hline FF34 & 510112.7 & 4441927.8 & 144.7 & Fine Sand & Moderately Sorted & Fine Skewed & Very Leptokurtic \\
\hline FF35 & 510969.8 & 4441883.8 & 280.7 & Medium Sand & Moderately Sorted & Coarse Skewed & Platykurtic \\
\hline FF36 & 510934.2 & 4441841.8 & 881.2 & Coarse Sand & Moderately Sorted & Symmetrical & Mesokurtic \\
\hline
\end{tabular}

\subsection{Mineralogical and Geochemical Analyses}

Total organic matter (TOM) content was determined by weight difference of dry sediment before and after to destroy sedimentary organic matter with hydrogen peroxide 30\% $(\mathrm{v} / \mathrm{v})$. This analysis was performed only in 34 samples due to the scarcity of sediment collected in stations FF3 and FF10.

Mineralogical and geochemical analyses were carried out in sedimentary fine fraction in the X-Ray Diffraction and Geochemical laboratories, respectively, of Geosciences Department, of Universidade de Aveiro. Only 14 sediment samples, with enough amount of fine fraction, were submitted to mineralogical and geochemical analyses.

To obtain the mineralogical data, X-Ray Diffraction (XRD) techniques were applied, according to the methodology described by Martins et al. (2007). Geochemical analysis was performed by ICP-MS (Inductively Coupled Plasma Mass Spectrometry) after multi-acid digestion of the sediments $\left(\mathrm{HCl}+\mathrm{HNO}_{3}+\mathrm{HF}\right)$. Concentrations of 21 chemical elements are analyzed in this work: Ag, Al, As, Ba, Ca, Cd, Co, Cr, Cu, Fe, K, Mg, Mn, $\mathrm{Mo}, \mathrm{Na}, \mathrm{Ni}, \mathrm{Pb}, \mathrm{Tl}, \mathrm{U}, \mathrm{V}$ and $\mathrm{Zn}$. Concentrations of Be were also determined but were low in most of the samples and less than the detection capacity of the equipment. The analytical precision was determined by inserting duplicates to approximately $10 \%$ of the samples. Analytical accuracy was determined by means of using standard reference materials. The results were within the $95 \%$ confidence limits of the recommended values for these certified materials. Analytical precision was about $4 \%$ for the analyzed trace elements.

\subsection{Statistical analysis}

Data selected for their relevance to this work (textural, mineralogical and geochemical) were statistically analyzed after being transformed by $\log (\mathrm{x}+1)$. Principal Components Analysis was carried out with Statistica 12 software. The maps were performed with the ArcGiz software 10.2 (datum WGS84).

\section{Results}

\subsection{Granulometric results}


Figure 2 presents a map of the spatial representation of sediment granulometry. It shows that fine and medium sand are the dominant classes in the study area. The medium and coarse sand classes are located at stations near the coast.

In the 36 studied stations, sediment mean grain size (SMGS) varied between $67.4-881.2 \mu \mathrm{m}$, which indicates that substrate is mostly composed of sandy sediments in the study area (Tables 1 and 2; Fig. 3A). Sand fraction content ranged from 100-77.8\% (mean $94.6 \%$ ), being fine fraction content $<38 \%$ (mean $4.8 \%$ ). Sediments of about $56 \%$ of the studied stations contain gravel fraction, $<5.1 \%$ (mean 0.64 $\%$ ). The stations with the highest percentages of gravel fraction are: FF36 (5.1\%) located at south of the FFH mouth, near the Costa de Lavos; and FF17 (4.2\%) located close to the FFH mouth. The stations of the study area with larger and smaller sediments are FF36 (SMGS $881.16 \mu \mathrm{m}$ ) and FF1 (SMGS $67.42 \mu \mathrm{m}$ ), corresponding respectively to the classes of coarse sand and very fine sand. The sediments in the study area are, in general, moderately sorted, symmetrically distributed and leptokurtic.

\subsection{Mineralogical composition of sediments (14 stations)}

The results of the mineralogical composition of 14 samples (with enough fine fraction) are presented in Table 2. These results evidence that the sediments of FFH mouth are composed mainly of quartz (70.00-44.43\%; mean $54.02 \pm 6.81 \%$; Fig. 3B). The station with the highest quartz content is FF20 $(70.00 \%)$ and the one with the lowest amount of this mineral is FF34 (44.43\%).

Phyllosilicates also reach relatively high percentages in the study area (32.23-0.70\%; mean 20.43; Fig. 3C). The stations with the highest amounts of this type of minerals are FF23 (32.2\%), FF1 (28.9\%) and FF14 (28.2\%). The lowest amount of these minerals was found in FF24 (0.70\%). Plagioclase (18.55-2.99\%; mean 10.26\%; Fig. 3D) and Kfeldspar (11.85-2.26\%: mean 7.60\%; Fig. 3E) are minerals very common in the study area. Stations with the highest percentages of plagioclase are FF13 (18.6\%) and FF15 $(18.2 \%)$. The stations FF24 (11.9\%) and FF13 (10.7\%), display the highest $\mathrm{K}$-feldspar content. The lowest plagioclase and $\mathrm{K}$-feldspar contents were recorded in the station FF5, with $2.99 \%$ and $2.26 \%$, respectively. Calcite is an accessory mineral present in all analyzed samples (0.93$6.34 \%$, mean 3.145; Fig. 3F). The highest percentage of calcite was found in the station FF14 (6.34\%) and the lowest in FF13 $(0.93 \%)$. Other minerals with rare or less expressive occurrences include for instance: pyrite $(<4.03 \%$, mean $0.49 \%)$, halite $(<3.97 \%$, mean $1.10 \%)$, siderite $(2.82 \%$; mean
$0.72 \%)$ and anhydrite $(<2.07 \%$, mean $1.02 \%)$. Dolomite, magnetite/maghemite and hematite were trace minerals.

Tab. 2. Maximum (max.), minimum (Min.) and mean values of the analysed variables in this work. Legend: SMGS - Sediment Mean Grain Size. TOC - total organic matter.

\begin{tabular}{|c|c|c|c|c|}
\hline \multicolumn{2}{|c|}{ Variables } & Max. & Min. & Mean \\
\hline SMGS & $\mu \mathrm{m}$ & 354.79 & 67.42 & 170.70 \\
\hline Gravel Fraction & $\%$ & 0.01 & 0.00 & 0.00 \\
\hline Sand Fraction & $\%$ & 0.99 & 0.62 & 0.88 \\
\hline Fines Fraction & $\%$ & 0.38 & 0.01 & 0.12 \\
\hline TOC & $\%$ & 12.82 & 0.00 & 4.23 \\
\hline Quartz & $\%$ & 70.00 & 44.43 & 54.02 \\
\hline K-Feldspars & $\%$ & 11.85 & 2.26 & 7.60 \\
\hline Plagioclase & $\%$ & 18.55 & 2.99 & 10.26 \\
\hline Calcite & $\%$ & 6.34 & 0.93 & 3.14 \\
\hline Dolomite & $\%$ & 3.14 & 0.00 & 0.22 \\
\hline Halite & $\%$ & 3.97 & 0.00 & 1.10 \\
\hline Siderite & $\%$ & 2.82 & 0.00 & 0.72 \\
\hline Phyllosilicates & $\%$ & 32.23 & 0.70 & 20.43 \\
\hline Anhydrite & $\%$ & 2.07 & 0.00 & 1.02 \\
\hline $\begin{array}{l}\text { Magnetite/ } \\
\text { Maghemite }\end{array}$ & $\%$ & 1.38 & 0.00 & 0.17 \\
\hline Hematite & $\%$ & 0.87 & 0.00 & 0.06 \\
\hline Pyrite & $\%$ & 4.03 & 0.00 & 0.49 \\
\hline $\mathrm{Ag}$ & $\mathrm{mg} / \mathrm{Kg}^{-1}$ & 0.18 & 0.03 & 0.07 \\
\hline Al & $\%$ & 1.22 & 0.52 & 0.84 \\
\hline As & $\mathrm{mg} / \mathrm{Kg}^{-1}$ & 12.86 & 7.78 & 9.49 \\
\hline $\mathrm{Ba}$ & $\mathrm{mg} / \mathrm{Kg}^{-1}$ & 27.51 & 12.21 & 19.99 \\
\hline $\mathrm{Ca}$ & $\%$ & 2.16 & 0.96 & 1.55 \\
\hline Cd & $\mathrm{mg} / \mathrm{Kg}^{-1}$ & 11.48 & 0.19 & 3.49 \\
\hline Co & $\mathrm{mg} / \mathrm{Kg}^{-1}$ & 4.82 & 2.13 & 3.29 \\
\hline $\mathrm{Cr}$ & $\mathrm{mg} / \mathrm{Kg}^{-1}$ & 28.05 & 11.56 & 17.32 \\
\hline $\mathrm{Cu}$ & $\mathrm{mg} / \mathrm{Kg}^{-1}$ & 13.14 & 4.86 & 7.32 \\
\hline $\mathrm{Fe}$ & $\%$ & 1.61 & 0.70 & 1.06 \\
\hline $\mathbf{K}$ & $\%$ & 0.32 & 0.12 & 0.22 \\
\hline $\mathbf{M g}$ & $\%$ & 0.80 & 0.32 & 0.52 \\
\hline Mn & $\mathrm{mg} / \mathrm{Kg}^{-1}$ & 152.48 & 73.69 & 108.14 \\
\hline Mo & $\mathrm{mg} / \mathrm{Kg}^{-1}$ & 1.14 & 0.57 & 0.78 \\
\hline $\mathrm{Na}$ & $\%$ & 2.59 & 0.01 & 0.77 \\
\hline $\mathbf{N i}$ & $\mathrm{mg} / \mathrm{Kg}^{-1}$ & 16.97 & 8.26 & 11.61 \\
\hline $\mathrm{Pb}$ & $\mathrm{mg} / \mathrm{Kg}^{-1}$ & 14.26 & 7.00 & 9.96 \\
\hline $\mathrm{T} 1$ & $\mathrm{mg} / \mathrm{Kg}^{-1}$ & 0.22 & 0.04 & 0.11 \\
\hline $\mathbf{U}$ & $\mathrm{mg} / \mathrm{Kg}^{-1}$ & 2.06 & 1.08 & 1.46 \\
\hline V & $\mathrm{mg} / \mathrm{Kg}^{-1}$ & 21.15 & 9.17 & 13.46 \\
\hline
\end{tabular}




\begin{tabular}{|l|l|l|l|l|}
\hline $\mathbf{Z n}$ & $\mathrm{mg} / \mathrm{Kg}^{-1}$ & 82.99 & 32.86 & 54.08 \\
\hline
\end{tabular}

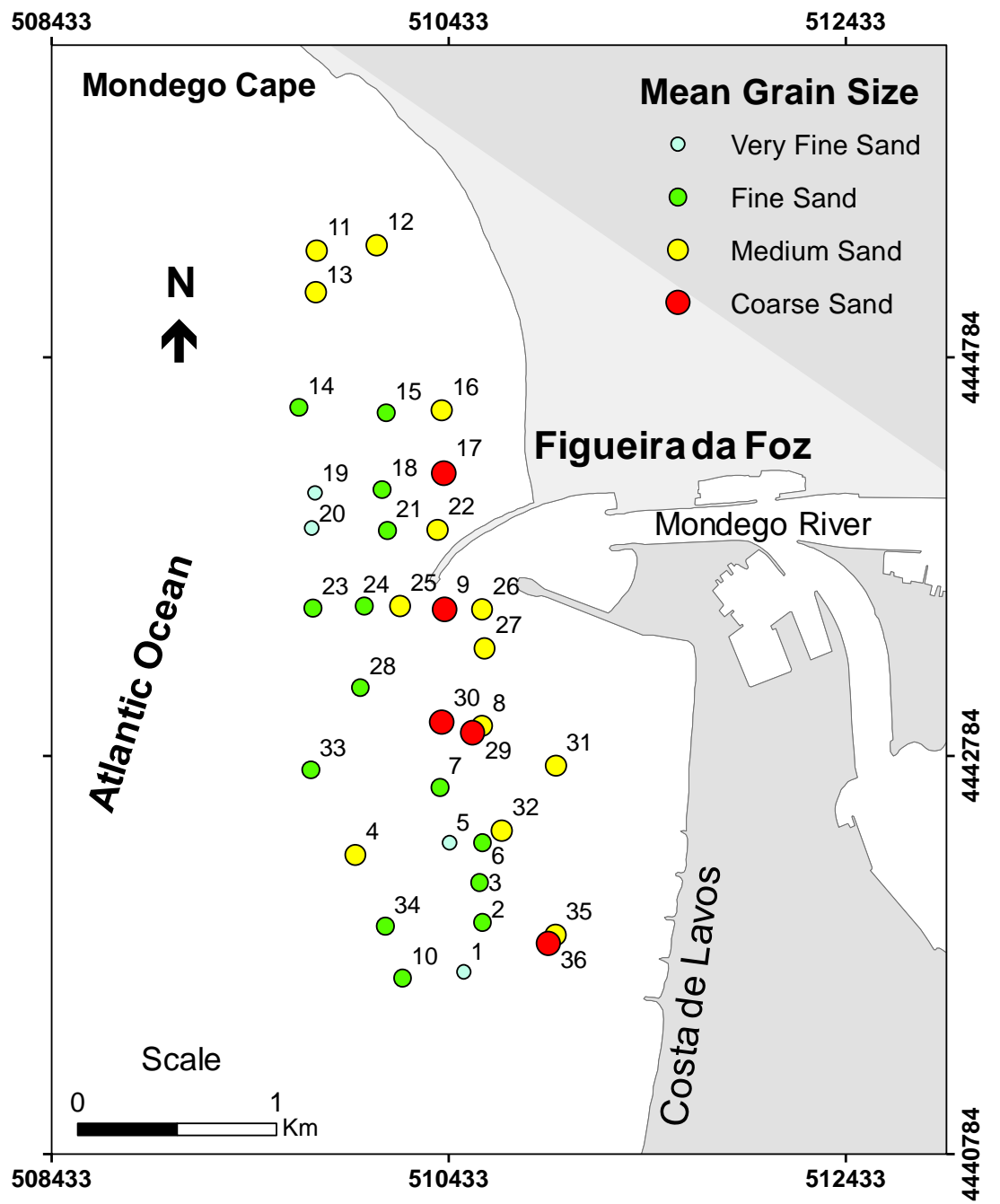

Fig. 2. Spatial distribution of the sediment granulometry (based on sediment mean grain size values) in the studied stations (signed with balls and numbers) at the mouth of the Figueira da Foz Harbour.

Plagioclase, K-feldspar and calcite contents reach the highest values close to the FFH mouth. Phyllosilicates contents increase at stations farther from the FFH mouth. Quartz does not vary significantly in most of the stations.

\subsection{Geochemical results (14 stations)}

Total organic matter (TOM) content is $<12.82 \%$ (mean $4.23 \%)$. The sample with the highest organic matter content is FF5 $(12.82 \%)$ and the lowest content is FF23 (0.89\%). TOM contents close to the mean value for the study area $(4.23 \%)$ were found in most of the stations. The highest
TOM contents were found far from FFH mouth (Fig. 4A). Table 2 presents the range of the chemical elements concentrations in 14 stations. The distribution of: i) some trace chemical elements concentrations, such as $\mathrm{Zn}, \mathrm{Cr}, \mathrm{V}$, As and $\mathrm{Cd}$ is shown in Fig. 4B-F; and ii) major chemical elements contents ( $\mathrm{Al}, \mathrm{Ca}, \mathrm{Fe}, \mathrm{K}, \mathrm{Na}$ and $\mathrm{Mg}$ ) are presented in Fig. 5A.

Major elements include, by descending order of concentration: $\mathrm{Ca}$ (mean $1.55 \%$ ), $\mathrm{Fe}$ (mean $1.06 \%$ ), $\mathrm{Al}$ (mean $0.84 \%$ ), $\mathrm{Na}$ (mean $0.77 \%$ ), $\mathrm{Mg}$ (mean $0.52 \%$ ) and $\mathrm{K}$ (mean $0.22 \%$ ). The highest elemental concentrations were reached in: $\mathrm{Ca}$ in station FF24 (1.16\%); Al, Fe and $\mathrm{K}$ in station FF5 
$(1.61 \%, 1.22 \%$ and $0.32 \%$, respectively); $\mathrm{Na}$ and $\mathrm{Mg}$ in stations FF13 $(2.59 \%)$ and FF3 $(0.80 \%)$, respectively. The lowest elemental concentrations were found: in $\mathrm{Fe}(0.70 \%)$, $\mathrm{Mg}(0.32 \%)$ and $\mathrm{K}(0.12 \%)$ in station FF33; and in $\mathrm{Ca}, \mathrm{Al}$ and $\mathrm{Na}$ in stations FF14 (0.96\%), FF24 (0.52\%) and FF20 $(0.01 \%)$, respectively. 

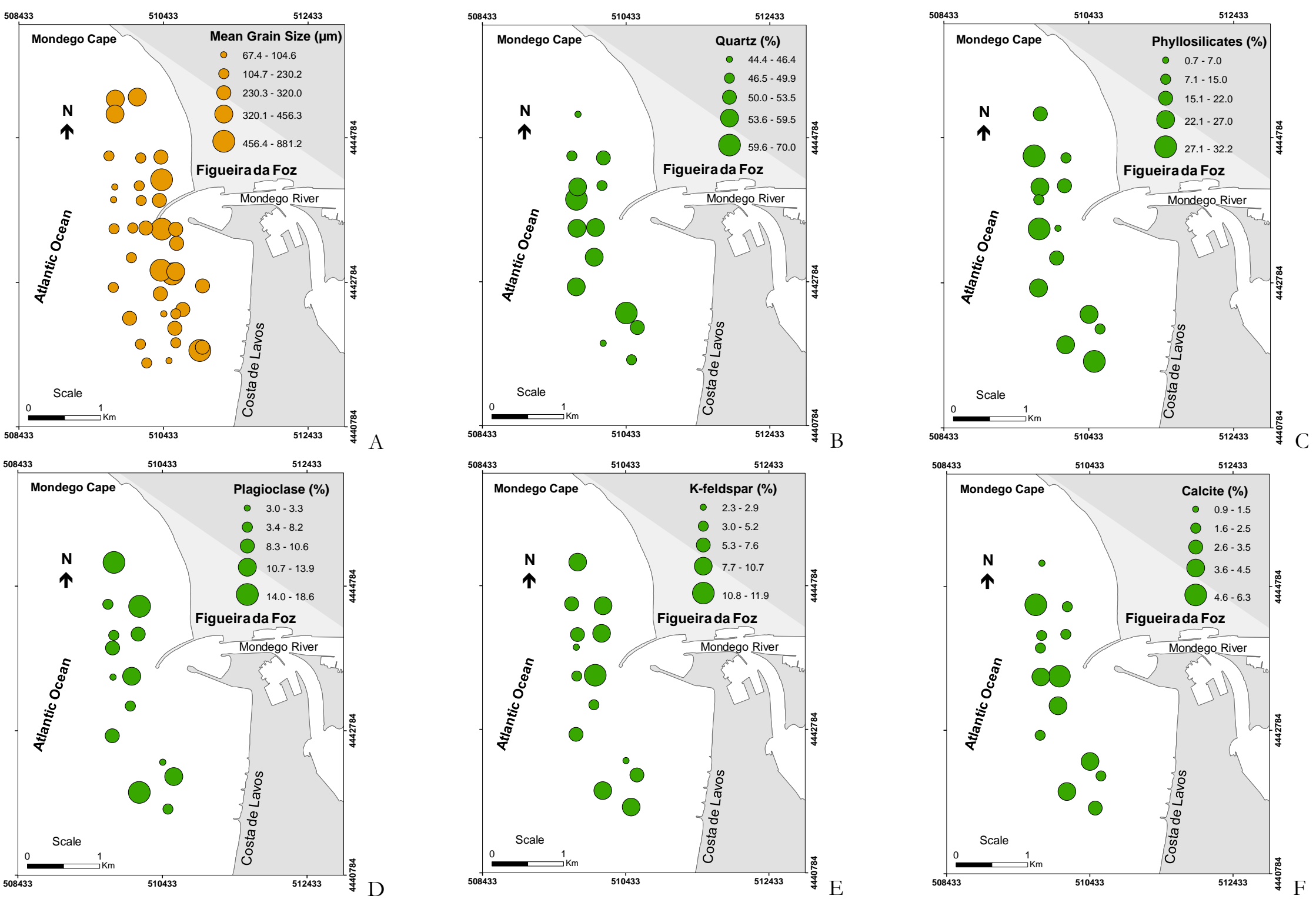

Fig. 3. Spatial distribution of (A.) sediment mean grain size ( $\mu \mathrm{m})$ and the main minerals $(\%)$ found off the mouth of Figueira da Foz Harbour: B. Quartz (\%); C. Phyllosilicates (\%); D. Plagioclase (\%); E. K-feldspar (\%); and F. Calcite. 

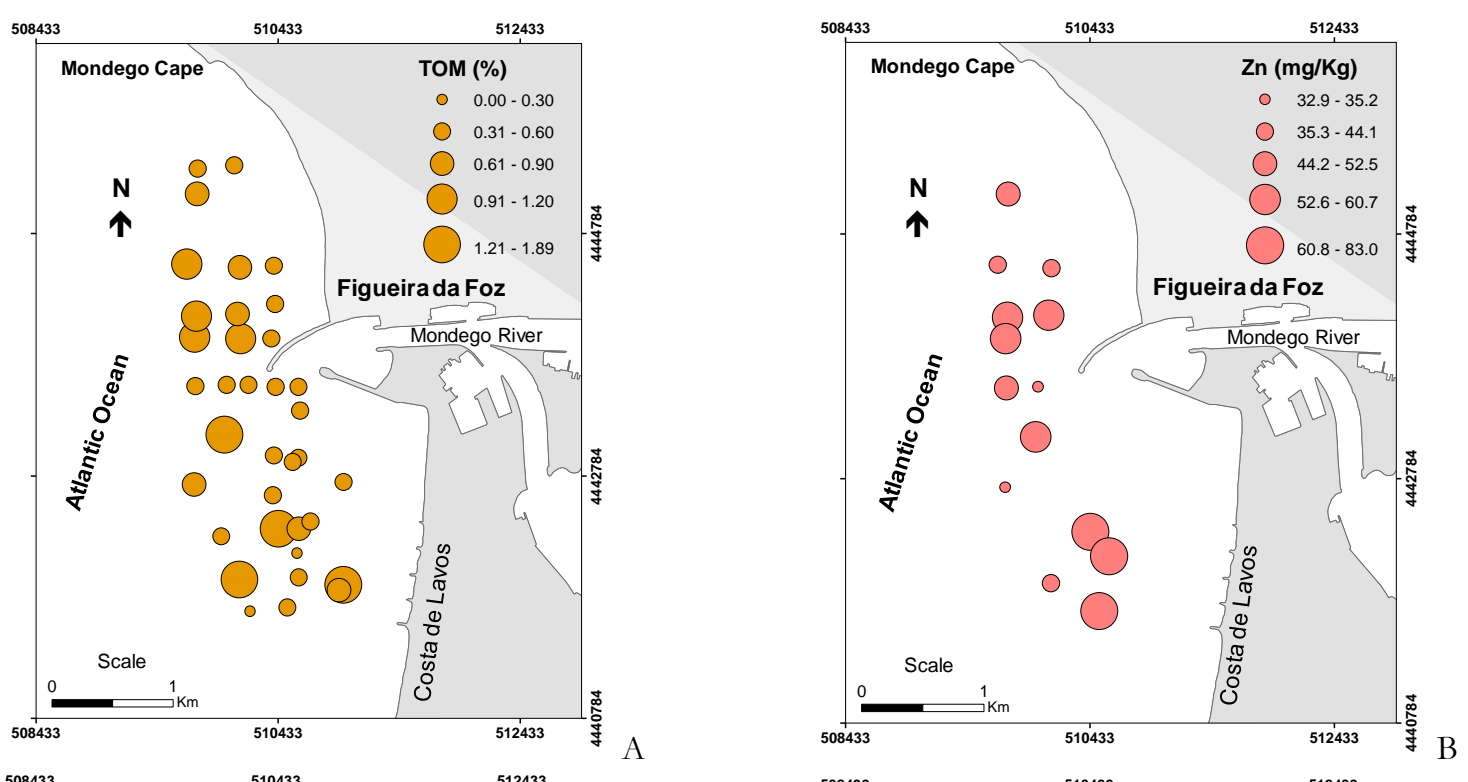

RESEARCH PAPER
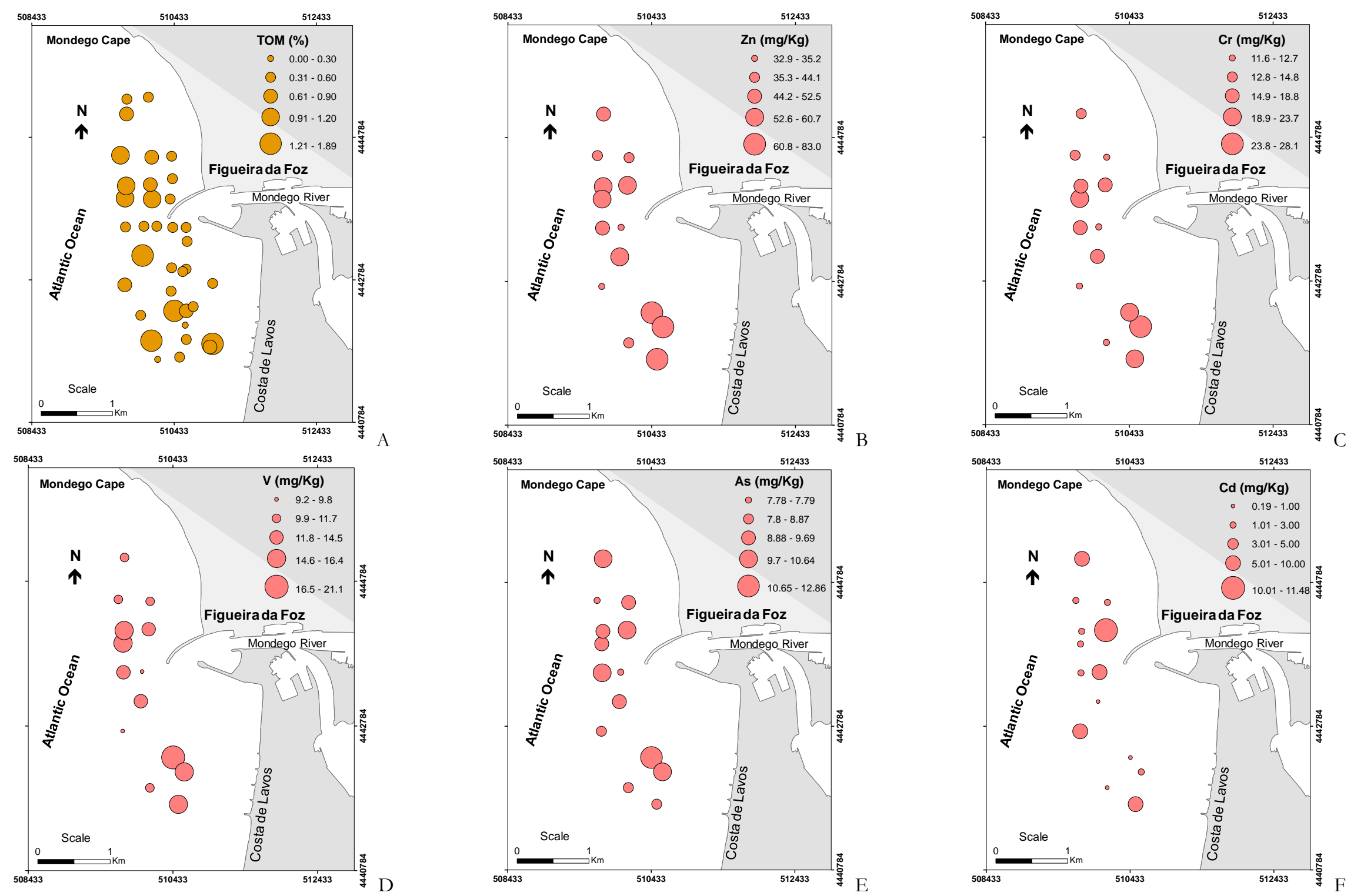

Fig. 4. Maps of distribution of (A.) TOM (\%) and trace elements (in $\mathrm{mg} \mathrm{kg}^{-1}$ ) of sediment samples collected off the mouth of Figueira da Foz Harbour: B. - Zn; C. - Cr; D. - V; E. - As; and F. - Cd. 


\subsection{Statistical results}

The PCA based on selected textural, mineralogical and geochemical data (obtained in the fine fraction of 14 sampling stations) was included in Fig. 6. Quartz was not considered in this analysis because it has small variability in most of the samples. Factor 1 against Factor 2 explains 68\% of data variability ( $49 \%$ and $19 \%$, respectively) and allows to identify 4 main groups of variables. Group I, containing SMGS, plagioclase and K-feldspar, is in opposition to group II, which contains most of the chemical elements, as well as fine fraction and phyllosilicates contents. Group III includes the variables of group I and also halite, magnesite/maghemite, pyrite, $\mathrm{Na}$ and Cd. Group IV, opposite to group III, consists of fine fraction, TOM and calcite contents.

Figure 7 shows the results of Factor Score 1 (FS1) of the PCA presented in Fig. 6, which explains most of data variability, with the stations in ascending order of the values of this FS1. This plot allows to separate two main groups of stations: I. FF14, FF15, FF24, FF33 and FF34 (with the highest values of the FS1); and II. FF1, FF3, FF5, FF13, FF18, FF19, FF20, FF23 and FF28 (with the lowest values of FS1).

The stations with the highest values of the FS1 (FF14, FF15, FF24, FF33 and FF34) are characterized by: relatively low values of TOM, phyllosilicates, pyrite, $\mathrm{Al}, \mathrm{As}, \mathrm{Ba}, \mathrm{Co}$, $\mathrm{Cr}, \mathrm{Cu}, \mathrm{Fe}, \mathrm{Mg}, \mathrm{Mn}, \mathrm{Mo}, \mathrm{Na}, \mathrm{Ni}, \mathrm{Pb}, \mathrm{K}, \mathrm{V} \mathrm{Zn}$ and U; and relatively coarse sediments and high contents of $\mathrm{K}$-feldspar, plagioclase, calcite, siderite, anhydrite, $\mathrm{Na}$ and $\mathrm{Ca}$. The stations with the lowest values of FS1 (FF1, FF3, FF5, FF13, FF20, FF23 and FF28) have opposite characteristics.

\section{Discussion}

\subsection{General characteristics of the sediments off FFH mouth}

The predominance of sandy sediments in the study area (Fig. 2) reveals the prevalence of relatively high bottom hydrodynamic conditions. The stations with medium and coarse sand were located near the FFH mouth whereas fine sediments were found in more distant areas.

Medium and coarse sand should result from the contribution of relatively coarse sediments brought by Mondego River to the study area during floods and storm events. Rivers carry large amounts of sediments in suspension and on the bottom. Coarse sediments are deposited upon reaching the river mouth, where the currents become weaker due to the widening of the receiving basin (Iannace, 2009). Fine grained sediments are transported in general further downstream and are deposited by decanting in areas where currents are sufficiently weak (Thomas et al., 2001).

The predominance of moderately sorted and poorly sorted sediments in stations located off the FFH mouth may be allied to energy irregularities or torrential regimes. The presence of moderately well-sorted sediments found in 11 stations $(33.33 \%)$ can indicate selective transport influenced by the action of currents and waves on the depositional environment. The predominance of stations (about 44\%) with symmetrical distribution of the sediment particles, in detriment of coarse asymmetric and finely asymmetric curves (both in $22 \%$ of the stations), as well as very finely asymmetric (8\%) and very coarse asymmetric (3\%) distributions, should indicate a trend of steadiness between fine and medium sediment fractions in the study area. However, the observed asymmetries in the spatial distribution of sediment particles may indicate changes in the energy of the ambient.

According to Friedman (1967), asymmetry is the parameter that best defines the depositional environment. Duane (1964), in his study in Pamlico, North Carolina, observed that negative values of asymmetry are indicative of areas affected by processes of erosion, while positive values indicate deposition of sediments. However, it is necessary to be cautious in these inferences, because part of the sediments used in the determination of asymmetry can be inherited from a past depositional history, or, on the contrary, it can express only the last mode of transportation of sedimentary particles to the analyzed deposit (Pomerol et al., 2013).

Kurtosis analysis allows to determine the degree of mixing of different populations within the same sedimentary environment (Folk and Ward, 1957). In the study area, the mean value of kurtosis (1.25) indicates that sediments found in $25 \%$ of samples have leptokurtic and very leptokurtic curves. These results indicate selection of particles by bottom currents, which removed at least a sediment fraction. However, the predominant curves of the sediments in the study area are mesocurtic $(33.33 \%)$.

This curve suggests a normal distribution, between medium and fine sand classes, and sediments associated with moderate energy. Finally, the platykurtic curves (16.67\%) may reinforce the idea that in the study area there are subpopulations of coarse and fine sediment particles, which contribute to the poorly sorted $(16.67 \%)$ and very poorly sorted $(2.78 \%)$ sediments. These results allow us to suppose that the presence of coarse sediments in some stations may also result from the remobilization of fine particles by hydrodynamic processes. Waves place the particles in suspension and facilitate their transport by the currents (Pomerol et al., 2013). 

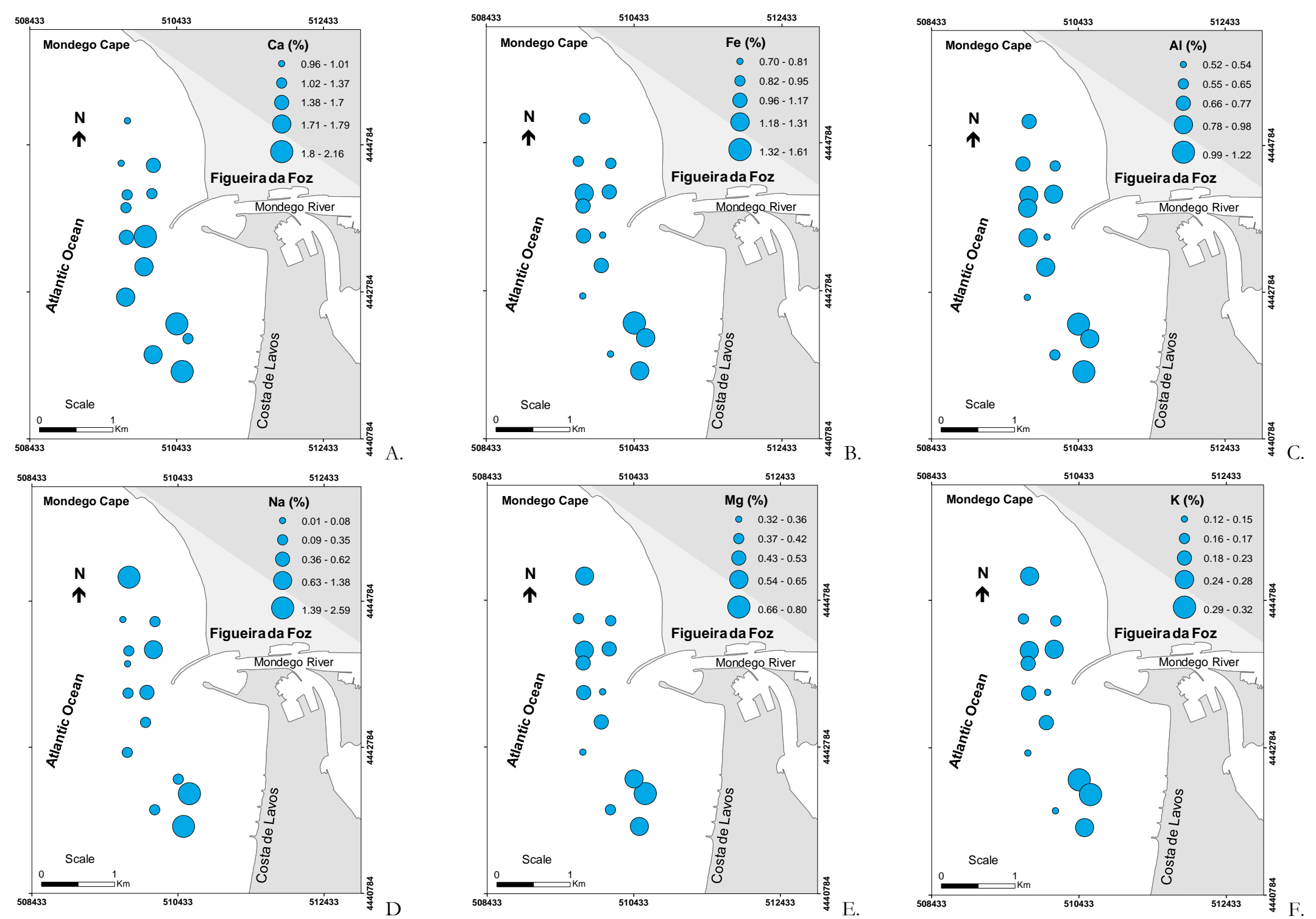

Fig. 5. Spatial distribution of the major elements concentrations of sediment samples collected off the mouth of Figueira da Foz Harbour: A. - Ca (\%); B. - Fe; C. - Al (\%); D. - Na (\%); E. - Mg (\%); and F - K (\%). 


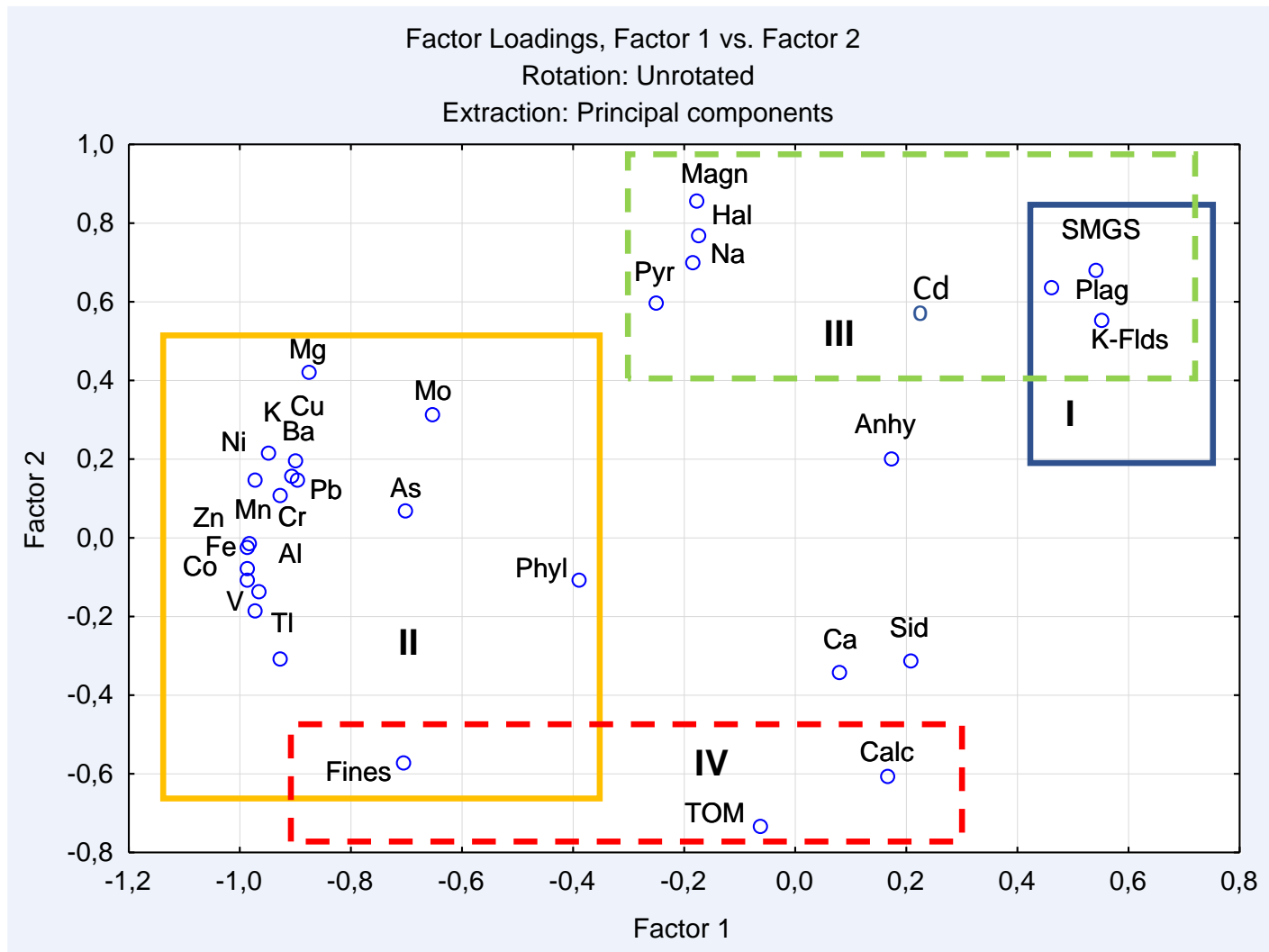

Fig. 6. Principal component analysis (PCA) based on data obtained from 14 stations in the study area. Legend: SMGS - sediment mean grain size; Fines - fine fraction $(<63 \mu \mathrm{m})$; Magn - magnesite/maghemite; Hal - halite; Pyr - pyrite; Plag - plagioclase; K-Flds - Kfeldspars; Phyl - phyllosilicates; Sid - siderite; Calc - calcite; TOM - total organic matter.

The PCA results (Fig. 6) indicate that the mineralogical and geochemical composition of bottom sediments of the study area are largely conditioned by sediment grain size, which in turn is related to hydrodynamic conditions. Fine fraction and phyllosilicates (Group II of PCA; Fig. 6) are positively related to most of chemical elements, except $\mathrm{Na}$, $\mathrm{Ca}$ and $\mathrm{Cd}$. Total organic matter, fines and carbonates are also positively related to each other (Group IV of PCA; Fig. 6).

The stations with the lowest values of FS1 (FF1, FF3, FF5, FF13, FF20, FF23 and FF28) display relatively high TOM, phyllosilicates, pyrite, $\mathrm{Al}, \mathrm{As}, \mathrm{Ba}, \mathrm{Co}, \mathrm{Cr}, \mathrm{Cu}, \mathrm{Fe}, \mathrm{Mg}$, $\mathrm{Mn}, \mathrm{Mo}, \mathrm{Na}, \mathrm{Ni}, \mathrm{Pb}, \mathrm{K}, \mathrm{V}, \mathrm{Zn}$ and $\mathrm{U}$ contents. These results suggest the occurrence of flocculation processes, or aggregation of fine sedimentary particles in the form of colloidal materials formed in response to ions' electrostatic forces.

Due to the interaction between salt water and fresh water, the water column stratification in the river's mouths is generally a common process: the salt water flows downwards towards the mouth (denser) and freshwater flows on the surface carrying fine particles in suspension towards the sea (Silvester and Hsu, 1997). However, there are points where the sediment movement of both streams along the interface between freshwater and salt water annuls each other, thus promoting sediment accumulation, whose location depends on the position of this interface and the tidal cycle. However, according to Pryor (1975), agglomerates of muddy sediments associated with organic matter can be deposited in slightly agitated waters. 


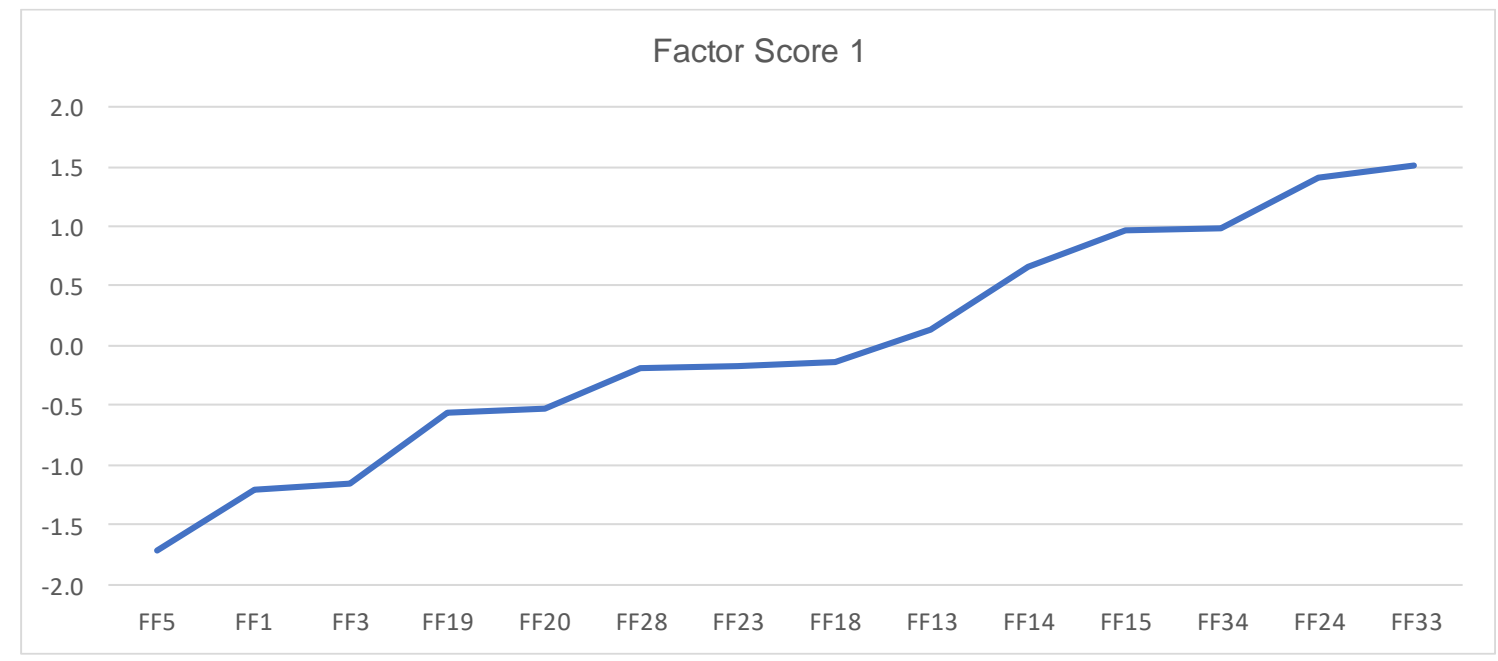

Fig. 7. Values of Factor Score 1 of the PCA of Figure 6, along the analyzed stations (FF) by increasing order of this factor score.

\subsection{Mineralogical composition of the sediments off FFH mouth}

The mineralogical composition of the sediments may be related to local and regional geology and, with processes inherent to its mechanical and chemical alteration, transported by the waters of Mondego River downstream. The abundance of quartz in the study area is certainly related to its chemical and physical resistance and to the occurrence of rocks outcropping along the Mondego River watershed, such as granite, quartzite and sandstones. But most minerals are weathered resulting in products of different composition. For example, $\mathrm{K}$-feldspar $\left(\mathrm{KAlSi}_{3} \mathrm{O}_{8}\right)$ degradation can give place to the formation of kaolinite $\left[\mathrm{Al}_{2} \mathrm{Si}_{2} \mathrm{O}_{5}(\mathrm{OH})_{4}\right]$.

The results of the PCA (Fig. 6) indicate that plagioclase, $\mathrm{K}$-feldspar and sediment mean grain size are positively related. The presence of plagioclase and $\mathrm{K}$-feldspar in all the analyzed stations, particularly in FF3, FF13, FF15, FF24 and FF34, indicate proximity to the source area of the sediments (e.g. granite weathering). Feldspars represent one of the most abundant group of minerals constituent of igneous rocks. They are major constituents of pegmatites and are common in mineral slugs. They can also occur in rocks that have undergone metamorphism and are also important constituents of less ancient sediments, being more frequent in continental sands (torrential, fluvial and wind) than in marine one due to rapid degradation (Carvalho, 2005).

Phyllosilicates (mean 20.43\%) may be related to the erosion of metamorphic, magmatic and sedimentary rocks of the region. The planar habit of phyllosilicates (micas, talc and clay minerals) can facilitate their transport in suspension and deposition in relatively calm waters.

Sodium is positively related to halite $(\mathrm{NaCl})$ reflecting the composition of this mineral. In addition to halite, $\mathrm{Na}$ can also occur in other minerals such as plagioclase and $\mathrm{K}$ feldspar (PCA, Group III; Fig. 6).

The presence of calcite $\left(\mathrm{CaCO}_{3}\right)$ in the study area (mean $3.14 \%$ ), may result from the weathering of carbonate rocks, for instance, in Costa de Arnes limestone (Coimbra), biogenic carbonates (such as mollusks shells and tests of foraminifera) and cement of sedimentary rocks (e.g. sandstone). However, calcite is positively related to TOM (PCA, Group IV; Fig. 6), which should indicate that this mineral is being mainly provided by biogenic particles, because organic matter present in the sediment may be used as food for the benthic fauna. Thus it can be assumed that organisms with shells and carbonate testes, such as mollusks and foraminifera, should be suppliers of calcite to the sediments of the study area.

\subsection{Geochemical composition of the sediments off FFH mouth}

The concentration of most of the chemical elements identified in the present study may be related to regional and local geology. Metals are normally distributed in the environment since they are natural constituents of rocks, sediments and soils. Significant increases in trace elements concentrations may be also related to anthropogenic pollution. 
In the study area, the elemental concentrations are positively related to fine fraction and phyllosilicates (Group II of PCA; Fig 6). The deposition of fine grained sediments with high phyllosilicates contents are in general associated with low hydrodynamic conditions which are also favorable to the deposition of organic matter. In addition, phyllosilicates may have positive or negative charges at the interfaces of their layers, which allows the adsorption of ions. This phenomenon may contribute to the accumulation of fine sediments rich in organic matter associated with relatively high concentrations of several chemical elements. Flocculation processes should contribute to the increase of sediments deposition rate (Pryor, 1975; Pomerol et al., 2013).

Cadmium, $\mathrm{Ca}$ and $\mathrm{Na}$ present different distributions from the other elements (PCA, Group III; Fig. 6). The concentrations of these elements tend to increase in coarse sediments with relatively high plagioclase, K-feldspars, magnetite/maghemite and pyrite contents. These results indicate the same route of supply for these elements and for those minerals related to Mondego River outflow.

The concentrations of $\mathrm{As}, \mathrm{Cr}, \mathrm{Cu}, \mathrm{Pb}, \mathrm{Ni}$ and $\mathrm{Zn}$ are low in the study area, compared to that found in other coastal regions of Portugal (Pereira et al., 2012; Martins et al., 2014, 2015). But Cd concentrations (mean value $3.49 \mathrm{mg} \mathrm{kg}^{-1}$ ) analysed in 14 stations can be considered relatively high according to the Portuguese regulation (Portaria n. ${ }^{\circ}$ 1450/2007).

\subsection{Environmental suitability of sediments off FFH mouth}

According to the Portuguese Ministerial Order n. ${ }^{\circ}$ 1450/2007 (Portaria n. ${ }^{\circ} 1450 / 2007$ ), five categories can be considered for dredged sediments. According to this regulation, the sediments with concentrations of $\mathrm{Cd}:<1 \mathrm{mg}$ $\mathrm{kg}^{-1}$ are from Class 1; between 1-3 $\mathrm{mg} \mathrm{kg}^{-1}$ are from Class 2; between 3-5 $\mathrm{mg} \mathrm{kg}^{-1}$ are from Class 3; between 3-5 mg kg-1 are from Class 4 and; $>10 \mathrm{mg} \mathrm{kg}^{-1}$ are from Class 5 .

Figure 8 shows the sediments evaluation based on the mentioned Portuguese regulation, for the spatial distribution of Cd contents in 14 stations off FFH mouth (Table 3). According to the mentioned regulation, the analysed sediments belong to: Class 1 - clean; Class 2 - material with trace contamination; Class 4 - contaminated material and; Class 5 - highly contaminated material. The most enriched stations by Cd are FF18 (11.48 $\mathrm{mg} \mathrm{kg}^{-1}$; Class 5), FF24 (6.80 mg kg-1; Class 4), FF13 (6.14 $\mathrm{mg} \mathrm{kg}^{-1}$; Class 4) and FF33 (5.33 $\mathrm{mg} / \mathrm{kg}^{-1}$; Class 4). These results indicate that some stations should have undesirable concentrations of $\mathrm{Cd}$.
Tab. 3. Cadmium contents in the sedimentary fraction $(<63 \mu \mathrm{m})$ and their classification based on the Portuguese regulation (Portaria n. ${ }^{\circ}$ 1450/2007). Reference value $<1 \mathrm{mg} \mathrm{kg}^{-1}$.

\begin{tabular}{|c|c|c|}
\hline Station & {$\left[\right.$ Cd] $\left(\mathbf{m g ~ k g} \mathbf{~}^{-1}\right)$} & Qualification \\
\hline FF1 & 5.59 & Classe 4 \\
\hline FF3 & 2.99 & Classe 2 \\
\hline FF5 & 0.19 & Classe 1 \\
\hline FF13 & 6.14 & Classe 4 \\
\hline FF14 & 2.78 & Classe 2 \\
\hline FF15 & 1.35 & Classe 2 \\
\hline FF18 & 11.48 & Classe 5 \\
\hline FF19 & 2.20 & Classe 2 \\
\hline FF20 & 1.43 & Classe 2 \\
\hline FF23 & 1.24 & Classe 2 \\
\hline FF24 & 6.80 & Classe 4 \\
\hline FF28 & 0.83 & Classe 1 \\
\hline FF33 & 5.33 & Classe 4 \\
\hline FF34 & 0.57 & Classe 1 \\
\hline
\end{tabular}

Cadmium may have natural sources, such as cadmium sulfide, and tend to occur in association with $\mathrm{Zn}$ in rocks (Reimann and Caritat, 1998). However, the increase of $\mathrm{Cd}$ in the study area should be associated with anthropic contamination. Cadmium has been widely released into the environment through mining and smelting, metal plating, pigments producing, usage of phosphate fertilizers, sewage sludge, and several industrial uses such as NiCd batteries, pigments and stabilizers (Agency for Toxic Substances and Disease Registry, 1990).

One of the potential ways of introducing materials into aquatic ecosystems by anthropic action is related to port activity and shipbuilding and repair. Navigation along the Portuguese mainland coast, open-air tank washing, commercial ports located in urban areas, handling of dangerous cargo and maritime accidents can be potential sources of seabed pollution (EP solos e sedimentos, 2012).

The presence of significant concentrations of hazardous substances from human activities may give rise to significant risk to human health and/or to the environment (EP solos e sedimentos, 2012). Cadmium in high concentrations can provoke environmental problems. It is an element with biomagnification effect and is a potential carcinogen for humans. 
"Short-term" ingestion may cause stomach problems, swelling of the face, neck and throat, difficulty in breathing and, in rare cases, may be fatal. "Long-term" ingestion leads to kidney failure. "Short-term" inhalation may cause irritation of the respiratory tract, shortness of breath or headaches; "Long-term" inhalation causes renal failure and decreases lung function (EP solos e sedimentos, 2012).

Considering that the highest elemental concentrations have been found in fine grained sediments, it may be assumed that most part of the studied stations with coarse sediments have low concentrations of trace elements and thus do not exhibit any type of contamination. They are from Class 1. According to the Portuguese regulation, dredged material of Class 1 is clean and can be deposited in the aquatic environment or replaced in places subject to erosion or used for beaches feeding without restrictive standards.

If dredging takes place on site/s: FF3, FF14, FF19, FF20, and FF23 (Class 2) the dredge material with trace contamination can be immersed in the aquatic environment taking into account the characteristics of the receiving environment and its legitimate use; FF1, FF13, FF24 and FF33, contaminated dredged materials (Class 4) can be deposited on land, in a waterproofed place; FF18, highly contaminated dredged materials (Class 5) should be sent for prior treatment and/or dump of duly authorized waste, being prohibited their immersion.

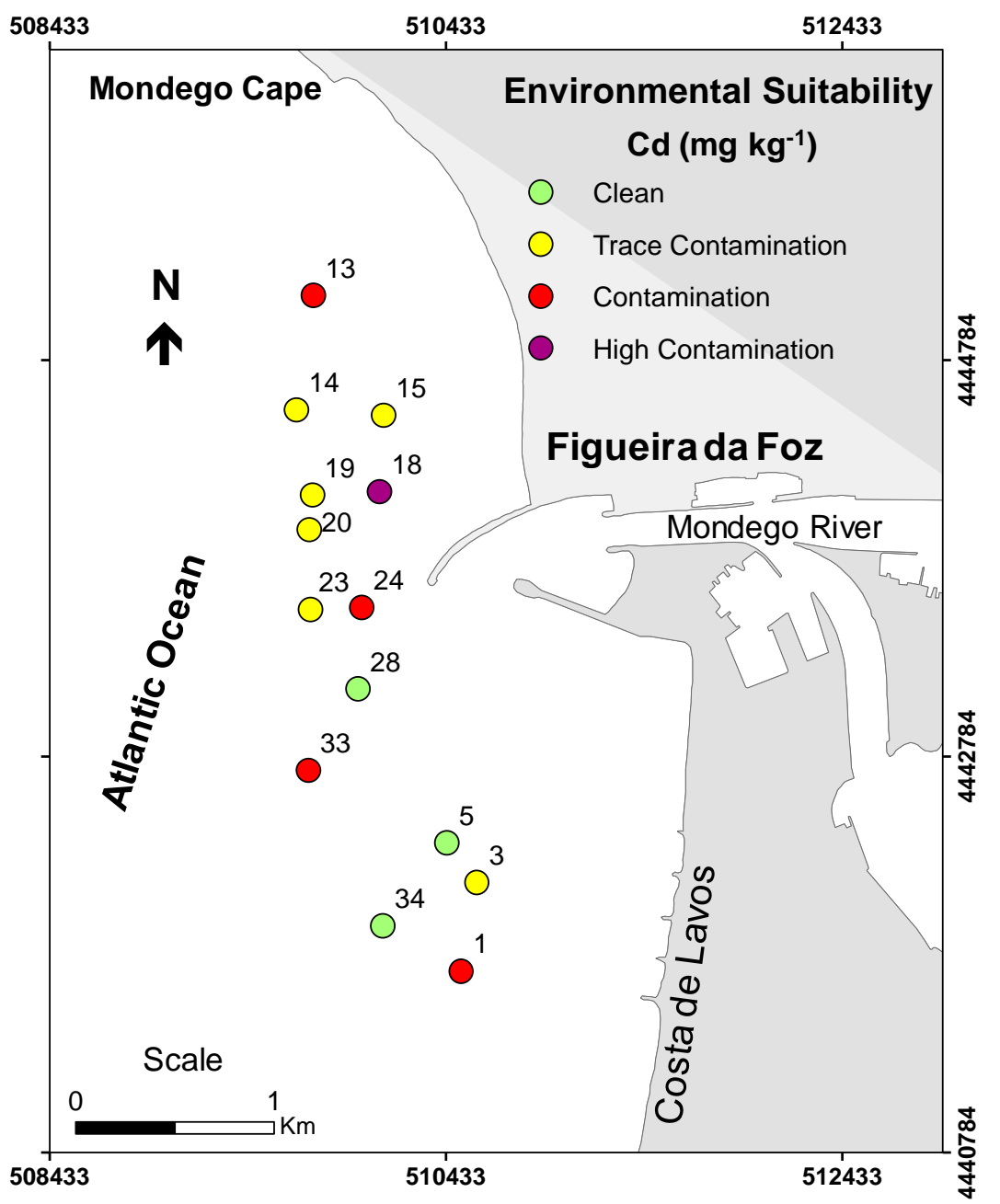

Fig. 8. Spatial distribution of the qualification of the environmental suitability of the sediments off the mouth of the Figueira da Foz Harbour in terms of Cd content, according to the Portuguese Regulation (Portaria n. ${ }^{\circ}$ 1450/2007). 
The places of immersion at sea are authorized by the competent authorities, taking into account the occurrence of particular features, such as marine aquaculture, between the coastline and bathymetry of $40 \mathrm{~m}$ (Portela, 2011). These requirements may give rise to an obligation to lodge the dredged material in areas far from where the dredging was carried out. However, there is a cost due to the distance between the dredging area and the dive site. A great distance between dredging areas and the immersion sites increases the costs involved in that operation.

\section{Conclusion}

The sediments found at the FFH mouth may be supplied by the Mondego River outflow and littoral drift. Most of the analyzed stations have clean sediments and therefore the dredging of materials can be deposited in the aquatic environment or replaced in places subject to erosion or used for beach nourishment without restrictions.

However, five stations seems to have contaminated (Class 4; FF1, FF13, FF24 and FF33) or highly contaminated sediments (FF18) by Cd. Dredging operations in these stations must be avoid without further studies and subsequent monitoring activities to analyze if contamination is persistent in these stations. The analysis of the negative effect of this contamination on benthic living beings is recommended.

\section{Acknowledgment}

The authors are grateful to Universidade Pedagógica de Moçambique and Universidade de Aveiro for the Master's degree fellowship given to the first author. The authors would also like to thank the samples availability and the support given in data acquisition. The acquisition of mineralogical and geochemical data was supported by the project UID/GEO/04035/2013 of FCT, of the Portuguese Science and Technology Foundation.

\section{References}

Abecasis, F., Matias, M.F., Carvalho, J.J., Vera-Cruz, D., 1962. Methods of determining sand and silt movement along the coast, in estuaries and in maritime rivers. Laboratório Nacional de Engenharia Civil, Lisboa, Technical paper n. ${ }^{\circ}$ 1, 25.

Agency for Toxic Substances and Disease Registry, 1990. Case studies in environmental medicine: Cadmium toxicity. Atlanta, GA: Agency for Toxic Substances and Disease Registry.

Bacelar-Nicolau, P., Nicolau, L. B., Marques, J. C., Morgado, F., Pastorinho, R., and Azeiteiro, U. M., 2003. Bacterioplankton dynamics in the Mondego estuary (Portugal). Acta Oecologica, 24 (Suppl. 1), 67-75. doi.org/10.1016/s1146-609x(03)00016-x
Carvalho, A.M.G., 2005. Geologia Sedimentar Volume IISedimentologia. Âncora editor, 1. ${ }^{a}$ Edição Lisboa, Portugal.

Coelho, C., Silva, P.A., Pinheiro, L.A., Gonçalves, D.S. (Eds.), 2011. Dragagens: Fundamentos, Técnicas e Impactos. UA Editora, Aveiro, Portugal, p.279. ISBN 978-972-789-346-1

Cortesão, C., Vale, C., 1995. Metals in sediments of the Sado Estuary, Portugal. Marine Pollution Bulletin, 30 (1), 34-37. doi.org/10.1016/0025-326X(94)00119-T

Cunha, P.P., Campar, A., Ramos, A. Cunha, L., Dinis, L., 2006. Geomorphology and coastal dynamics of the Figueira da Foz Region. Publicações da Associação Portuguesa de Geomorfólogos, APGeom, Lisboa, vol. IV, pp. 35-46.

Cunha, P.P., Dinis, J., Silva, A.F., André, J.N., 1995. Evolução estuarina condicionada por intervenções portuárias: Modificações recentes no sector intermédio e distal do estuário do Mondego. Memórias e Notícias 120, 95-117.

Duane, D.B., 1964. Significance of skewness in recent sediments, Western Pamlico Sound, North Carolina. Journal of Sedimentary Petrology 34, 864-874. doi: 10.1306/74d711b82b21-11d7-8648000102c1865d

EP solos e sedimentos, 2012. Relatório de Actividades da EP solo e Sedimentos 2009/2011. Lisboa, Portugal.

Folk, R. R.L., Ward, W.W.C., 1957. Brazos River Bar: A study in the significance of grain size parameters. SEPM Journal of Sedimentary Research, $27 \quad$ (1), 3-26. doi.org/10.1306/74d70646-2b21-11d7-8648000102c1865d

Freire, P., Oliveira, F.S.B.F., Capitão, R., Fortes, C., 2004. Crossshore Evolution of Buarcos Beach, Portugal. In: Smith, J.M. (Ed.), Proc. 29th International Conference on Coastal Engineering, ASCE, 3, 2314-2326.

Friedman, G.M., 1967. Dynamic processes and statistical parameters compared for size frequency distribution of beach and river sands. Journal of Sedimentary Petrology 37 (2), $327-$ 354. doi: 10.1306/74d716cc-2b21-11d7-8648000102c1865d

Iannace, A., 2009. Sedimentation and Sedimentary Rocks. In: Geology, Vol. II, Sedimentation and Sedimentary Rocks, EOLSS Publisher, Oxford.

Kondolf, G.M., Gao, Y., Annandale, G.W., Morris, G.L., Jiang, E., Zhang, J., Cao, Y., Carling, P., Fu, K., Guo, Q., Hotchkiss, R., Peteuil, C., Sumi, T., Wang, H.-W, Wang, Z., Wei, Z., Wu, B., Wu, C., Yang, C.T., 2014. Sustainable sediment management in reservoirs and regulated rivers: Experiences from five continents. Earth's Future 2, 256-280. doi:10.1002/2013EF000184.

Luíz, C.I., Morgado, A., Pombo, J., Matos, M., 2006. Sedimentos superficiais da plataforma continental portuguesa entre Espinho e Figueira da Foz. VII Congresso Nacional de Geologia Sociedade Geológica de Portugal, pp. 2-5.

Martins, R., Azevedo, M.R., Mamede, R., Sousa, B., Freitas, R., Rocha, F., Quintino, V., Rodrigues, A.M., 2012. Sedimentary and geochemical characterization and provenance of the 
Portuguese continental shelf soft-bottom sediments. Journal of Marine Systems 91, 41-52. doi:10.1016/j.jmarsys.2011.09.011

Martins, M.V.A., Mane, M.A., Frontalini, F., Santos, J.F., Silva, F.S., Terroso, D., Miranda, P, Figueira, R., Laut, L.L.M., Bernardes, C., Filho, J.G.M., Coccioni, R., Rocha, F., 2015. Early diagenesis and adsorption by clay minerals important factors driving metal pollution in sediments. Environmental Science and Pollution Research, 22 (13), 10019-10033. DOI: 10.1007/s11356-015-4185-4.

Martins, M.V.A., Frontalini, F., Rodrigues, M.A,C., Dias, J.M.A., Laut, L,L.M. Silva, F.S., Clemente, I.M.M.M., Reno, R., Moreno, J., Sousa, S., Zaaboub, N., El Bour M., Rocha, F., 2014. Foraminiferal biotopes and their distribution control in Ria de Aveiro (Portugal): a multiproxy approach. Environmental Monitoring and Assessment 186(12), 88758897. doi: 10.1007/s10661-014-4052-7

Martins, V., Dubert, J., Jouanneau, J. M., Weber, O., Silva, E.F., Patinha, C., Rocha, F., 2007. A multiproxy approach of the Holocene evolution of shelf-slope circulation on the NW Iberian Continental Shelf. Marine Geology 239 (1-2), 1-18. doi.org/10.1016/j.margeo.2006.11.001

Paiva, R., 2011. Definição do campo de actividades de dragagens. In: Coelho, C., Silva, P.A.L., Pinheiro, M., Gonçalves, D.S. (Eds.), Dragagens: Fundamentos, Técnicas e Impactos. UA Editora, Aveiro, Portugal. ISBN 978-972-789-346-1

Paixão, G.L., 2004. Dredging and dredged material disposal in Portugal. In: Universidade Lusófona (Ed.), Dredging Seminar, Lisbon, Portugal.

Pereira, P., Carvalho, S., Pereira, F., Pablo, H., Gaspar, M.B., Pacheco, M., Vale, C., 2012. Environmental quality assessment combining sediment metal levels, biomarkers and macrobenthic communities: application to the Óbidos coastal lagoon (Portugal). Environmental Monitoring and Assessment. 184, 12, 7141-7151. doi: 10.1007/s10661-011-2486-8

Pomerol, C., Lagabrielle, Y., Renard, M., Guillot, S., 2013. Princípios de Geologia: técnicas, modelos e teorias. Editora Bookman. 14th ed., ISBN: 9788565837804

Portaria n. ${ }^{\circ}$ 1450/2007, de 12 de Novembro, do Ministério do Ambiente, do Ordenamento do Território e do Desenvolvimento Regional. Diário da República, 1. ${ }^{a}$ série N. ${ }^{\circ} 217$ - 12 de Novembro de 2007, p. 8372-8382.

Portaria n. o 209/2004, de 3 de Março, Diário da República 1-30 (2004). Portugal: Diário da República. Retrieved from http://www.ecolabor.pt/pdfs/Portaria_209_2004.pdf

Portela, L.I., 2011. Planeamento de Dragagens Portuárias. In: Coelho, C., Silva, P.A.L., Pinheiro, M., Gonçalves D.S. (Eds.),
Dragagens: Fundamentos, Técnicas e Impactos. UA Editora, Aveiro, Portugal, pp. 29-38.

Pryor, W.A., 1975. Biogenic sedimentation and alteration of argillaceous sediments in shallow marine environments. Geological Society of American Bulletin 86(6), 1244-1254. doi: 10.1130/0016-7606(1975)86<1244:bsaaoa>2.0.co;2

Reimann, C., Caritat, P., 1998. Chemical Elements in the Environment: factsheets for the geochimist and environmental. In: Raimann C., Caritat, P. (Eds.), I. Enveron, Verlag Berlin Heidelberg, Germany: Springer.

Rocha, S., Freitas, H., 1998. O Rio Mondego: o ambiente fluvial e a sua ecologia. O Congresso da Água, Lisboa, (1).

Silva, P.A., Coelho, C., Abreu, T., Baptista, P., Bernardes, C., Fontan Bouzas, Á., Vaz, N., 2015. Contribuição para o estudo da dinâmica sedimentar da embocadura do Porto da Figueira da Foz, Portugal. In: P. A. da Silva, C. Coelho, T. Abreu, P. Baptista, C. Bernardes, Á. Fontan Bouzas, N. Vaz (Eds.), VIII Congresso sobre Planeamento e Gestão das Zonas Costeiras dos Países de Expressão Portuguesa, pp. 1-15.

Silva, A.N., Taborda, R., Bertin, X., Dabet, G., 2012. Seasonal to Decadal Variability of Longshore Sand Transport at the Northwest Coast of Portugal. Journal of Waterway, Port, Coastal, and Ocean Engineering 6(138), 464-472.

Silva, P.A., 2011. Impactos da Exploração de Inertes na Plataforma Continental. In: Coelho, C., Silva, P.A.L., Pinheiro, M., Gonçalves D.S. (Eds.), Dragagens: Fundamentos, Técnicas e Impactos. UA Editora, Aveiro, Portugal, pp. 11-64.

Silvester, R., Hsu, J.R.S., 1997. Coastal stabilization. Advanced Series on Ocean Engineering, Volume 14. British: World Scientific. ISBN: 978-981-02-3137-8

Tamuno, P.B.L., Smith M.D., Howard, G., 2009. Good Dredging Practices: The Place of Traditional Eco-livelihood Knowledge. Water Resources Management 23, 1367-1385. doi 10.1007/s11269-008-9331-z

Thomas, S.A., Newbold, J.D., Monaghan, M.T., Minshall, G.W., Georgian, T., Cushing, C.E., 2001. The influence of particle size on seston deposition in streams. Limnology and Oceanography 46(6), 1415-1424.

Velosa, A., Cachim, P., 2011. Utilização de Dragados em Materiais de Construção. In: Coelho, C., Silva, P.A.L., Pinheiro, M., Gonçalves D.S. (Eds.), Dragagens: Fundamentos, Técnicas e Impactos, Universidade de Aveiro, Aveiro, Portugal, pp. 241255.

Verfaillie, E., Du Four, I., Van Lancker, V., Maes, F., Schrijvers, J., 2005. Dredging and disposal of dredged material. Towards a Spatial Structure Plan for Sustainable Management of the Sea: Mixed Actions-Final Report: SPSD II (MA/02/006), 150-162. 